\author{
Abstracta Iranica \\ Abstracta Iranica Revue bibliographique pour le domaine irano-aryen \\ Volume 32-33 | 2013 \\ Comptes rendus des publications de 2009-2010
}

\title{
Fabrizio Speziale. Soufisme, religion et médecine en Islam indien
}

\section{Mauro Valdinoci}

\section{(2) OpenEdition}

1 Journals

\section{Electronic version}

URL: http://journals.openedition.org/abstractairanica/40641

DOI: 10.4000/abstractairanica.40641

ISSN: 1961-960X

Publisher:

CNRS (UMR 7528 Mondes iraniens et indiens), Éditions de l'IFRI

\section{Printed version}

Date of publication: 1 December 2013

ISSN: 0240-8910

\section{Electronic reference}

Mauro Valdinoci, «Fabrizio Speziale. Soufisme, religion et médecine en Islam indien », Abstracta Iranica [Online], Volume 32-33 | 2013, document 282, Online since 01 July 2016, connection on 03 October 2020. URL : http://journals.openedition.org/abstractairanica/40641 ; DOI : https://doi.org/10.4000/ abstractairanica.40641

This text was automatically generated on 3 October 2020.

Tous droits réservés 


\title{
Fabrizio Speziale. Soufisme, religion et médecine en Islam indien
}

\author{
Mauro Valdinoci
}

\section{REFERENCES}

Fabrizio Speziale. Soufisme, religion et médecine en Islam indien. Paris, Karthala, 2010, 300 p., glossary, biblio., index.

1 This valuable contribution to studies on traditional medicine and its relation to religion and Sufism focuses on Delhi and the Deccan over a long period, from the establishment of the Delhi Sultanate (1206) to the end of the 20th century. Drawing on the methods of social and historical anthropology, the author combines ethnology with textual analysis. Among the primary sources examined, most of them in Persian or Urdu, are saints' biographies, Sufi writings, Sufi and non-Sufi works on medicine, and reports from archives.

2 The introduction deconstructs the underlying assumptions of the theory that Sufism has had a negative impact on medicine, which still prevails among Western historians and Orientalists; it demonstrates that this theory is mainly based on essentialistic oppositions and an ethnocentric view of medicine.

3 The first chapter provides a detailed historical overview while analyzing changes and continuities in the transmission of medical knowledge in Sufi circles in northern India. It shows how the role of Sufi masters in transmitting knowledge about traditional medicine (yūnānī) evolved over time.

4 The second chapter explores the Muslim medical and religious context in Hyderabad and the Deccan. After contextualizing the spread of Sufi orders in the area, it discusses the Sufis' interest, as well as the interest of Shiite and Sunnite ulemas in medicine, and describes a few Sufi shrines (sing. dargāh) that are renowned for their therapeutic practices. It examines a wide range of phenomena, such as therapeutic rituals 
performed at Sufi saints' graves, the spiritual healing practices of living Sufi masters and healing dreams.

The third chapter on the doctrinal aspects and methods of medicine argues that Sufi medicine is based on theories and practices drawn from Islamic and pre-Islamic sciences, which are traditionally considered as part of a coherent system for maintaining a balance between the laws of the physical and "subtle" worlds.

6 A major aim of the author is to show that Sufis did not object to scientific thought but, instead, contributed to the transmission of medical knowledge, the establishment of the Galenic medical school in India and its reform during the colonial period. A major strength of the book is its underlining of how important Persian texts on Indian medicine and pharmacology were for adapting Muslim medical practice to India. The author also analyzes the historical and intellectual factors that shaped the connection between yūnāni medicine and Sufism, and caused its decline in contemporary India. He claims that the reforms launched in the late 19th century and the more radical ones introduced after independence, such as the institution of new yūnāni university courses, hospitals and research centers, definitively shattered the roles played by families and private teachers as well as other aspects of the traditional transmission of medical knowledge (p. 241). The reforms "formalized the division between yūnāni medicine and the other Islamic sciences and the subordination of traditional medicine to biomedicine" (p. 241-242). The decline of the relation between Sufism and medicine is "both an aspect and an outcome of the process of separation of yūnāni medicine from the Islamic scientific and traditional knowledge" (p. 239-240). This book, based on extensive and original research, is a welcome resource for scholars interested in the history of science in the Muslim world; it should be on the reading list of persons working on the history of medicine in Islam.

\section{AUTHORS}

\section{MAURO VALDINOCI}

University of Modena and Reggio Emilia 